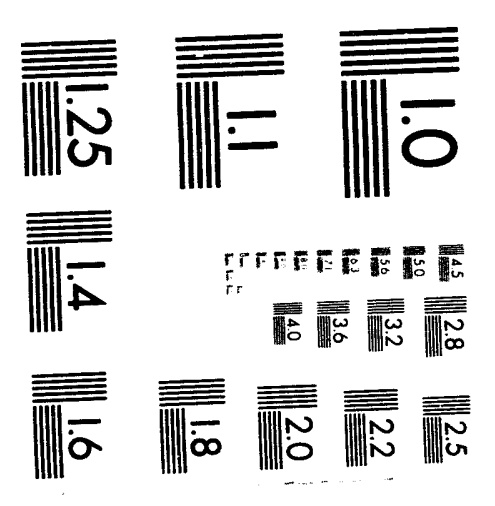



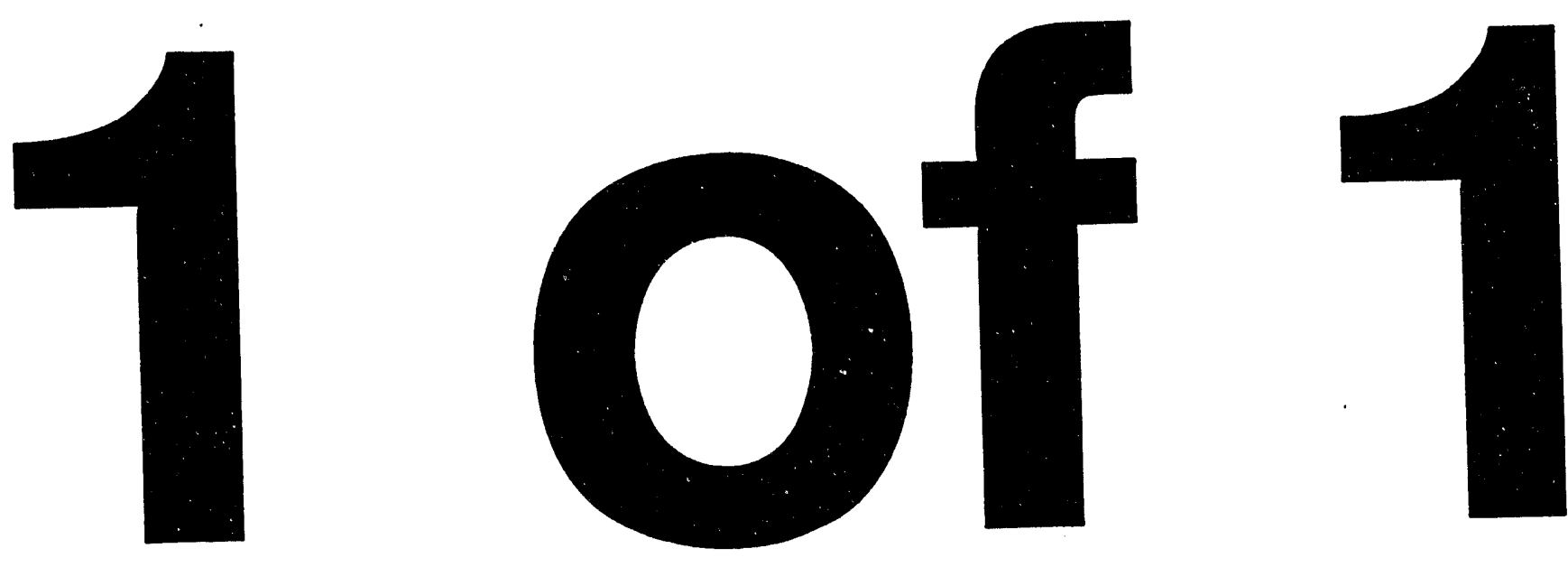


\title{
UMTRA PROJECT LIST OF REPORTABLE OCCURRENCES
}

\section{April 1994}

\author{
RECICIVED \\ MAY 121994 \\ OSTI
}

\section{DISCLAIMER}

This report was prepared as an account of work sponsored by an agency of the United States Government. Neither the United States Government nor any agency thereof, nor any of their employees, makes any warranty, express or implied, or assumes any legal liability or responsibility for the accuracy, completeness, or usefulness of any information, apparatus, product, or process disclosed, or represents that its use would not infringe privately owned rights. Reference herein to any specific commercial product, process, or service by trade name, trademark, manufacturer, or otherwise does not necessarily constitute or imply its endorsement, recommendation, or favoring by the United States Government or any agency thereof. The views and opinions of authors expressed herein do not necessarily state or reflect those of the United States Government or any agency thereof.

\section{MASTER}




\section{INTENDED FOR PUBLIC RELEASE}

This report has been reproduced from the best available copy. Available in paper copy and microfiche.

Number of pages in this report: 67

DOE and DOE contractors can obtain copies of this report from:

Office of Scientific and Technical Information

P.O. Box 62

Oak Ridge, TN 37831

(615) 576-8401

This report is publicly available from:

National Technical Information Service

Department of Commerce

5285 Port Royal Road

Springfield, VA 22161

(703) $487-4650$ 
UMTRA PROJECT LIST OF REPORTABLE OCCURRENCES

Draft

April 1994

Prepared for

U.S. Department of Energy UMTRA Project Office

Albuquerque, New Mexico

Prepared by

Jacobs Engineering Group Inc.

MK-Ferguson Company

Albuquerque, New Mexico 


\section{TABLE OF CONTENTS}

Section

Page

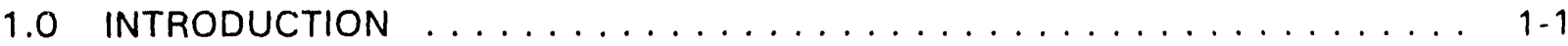

2.0 REPORTABLE OCCURRENCES FOR ACTIVE SITES $\ldots \ldots \ldots \ldots \ldots \ldots \ldots \ldots$

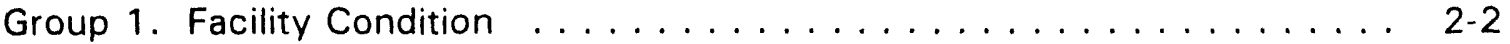

Group 2. Environmental . . . . . . . . . . . . . . . . . . . . . . 2-6

Group 3. Personnel Safety ... . . . . . . . . . . . . . . . . . . . 2-10

Group 4. Personnel Radiation Protection . . . . . . . . . . . . . . . . 2-12

Group 5. Safeguards and Security ..................... 2-14

Group 6. Transportation ........................... 2-17

Group 7. Value Basis Reporting . . . . . . . . . . . . . . . . . . . . 2-20

Group 8. Facility Status ... . . . . . . . . . . . . . . . . . . 2-21

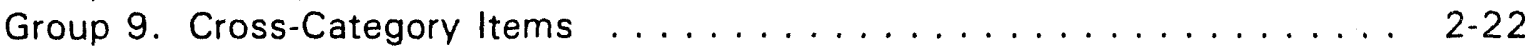

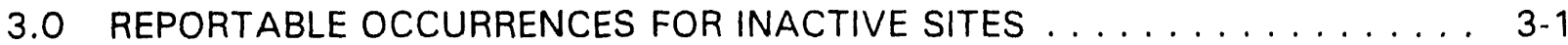

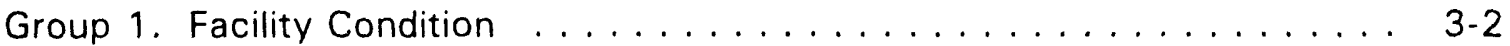

Group 2. Environmental ......................... 3-5

Group 3. Personnel Safety . . . . . . . . . . . . . . . . . . . . . . . . 3-9

Group 4. Personnel Radiation Protection .................. 3-11

Group 5. Safeguards and Security . . . . . . . . . . . . . . . $3-13$

Group 6. Transportation ........................ 3-16

Group 7. Value Basis Reporting .................... 3-17

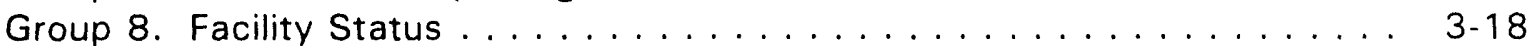

Group 9. Cross-Category Items ................. 3-19

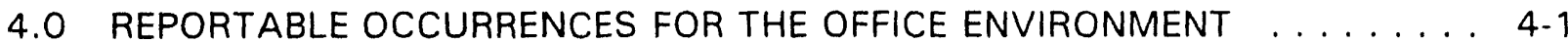

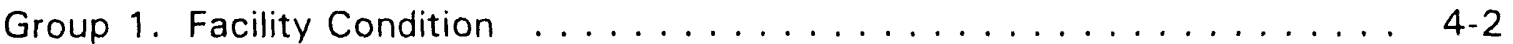

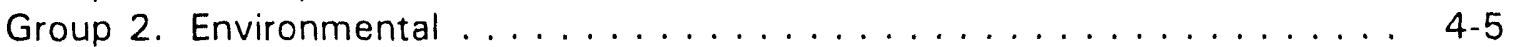

Group 3. Personnel Safety . . . . . . . . . . . . . . . . . . . . . . . 4-6

Group 4. Personnel Radiation Protection ... . . . . . . . . . . . . . . 4.7

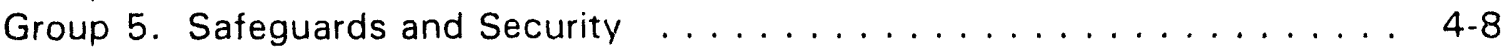

Group 6. Transportation ... . . . . . . . . . . . . . . . . . . . 4-11

Group 7. Value Basis Reporting . . . . . . . . . . . . . . . . . . . 4-12

Group 8. Facility Status . . . . . . . . . . . . . . . . . . . . . . . 4-13

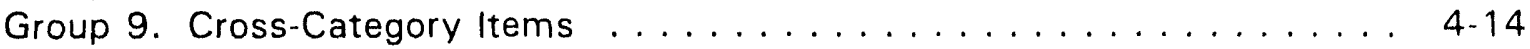

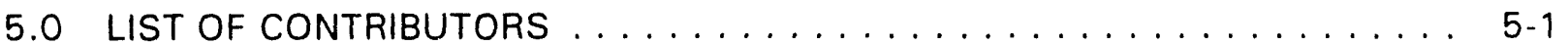

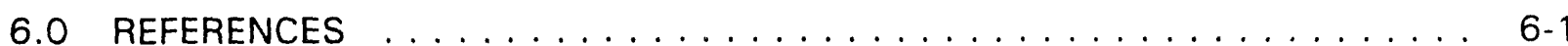




\section{LIST OF ACRONYMS AND ABBREVIATIONS}

\section{Acronym/Abbreviation Definition}

APO

CERCLA

DCG

DOE

DOT

ORPS

OSHA

RCRA

RO

UMTRA
Albuquerque Project Office

Comprehensive Environmental Response, Compensation and

Liability Act

Derived Concentration Guide

U.S. Department of Energy

U.S. Department of Transportation

Occurrence Reporting and Processing System

Occupational Safety and Health Act

Resource Conservation and Recovery Act

Reportable Quantity

Uranium Mill Tailings Remedial Action 


\subsection{INTRODUCTION}

This UMTRA Project List of Reportable occurrences is provided to facilitate efficient categorization of reportable occurrences. These guidelines have been established in compliance with DOE minimum reporting requirements under DOE Order 5000.3B. 


\subsection{REPORTABLE OCCURRENCES FOR ACTIVE SITES}

Occurrences are arranged into nine groups relating to U.S. Department of Energy (DOE) Uranium Mill Tailings Remedial Action (UMTRA) Project operations for active sites. These nine groupings are provided for reference to determine whether an occurrence meets reporting requirement criteria in accordance with the minimum reporting requirements contained in Attachment 1 of DOE Order 5000.3B. Event groups and significance categories that cannot or will not occur, and that do not apply to UMTRA Project operations, are omitted.

Depending on the nature of the event, an occurrence may be categorized in up to three groups. All groups that pertain to the occurrence should be identified. For example, a fire, occurs in an office trailer and is not extinguished within 10 minutes after arrival of fire protection personnel; as a result, an employee is injured and requires hospitalization, and loss to government property exceeds $\$ 10,000$. The categories that would apply to the occurrence are as follows:

- Group 1, Facility Condition; Subgroup B, Fires/explosions, Off-normal.

- Group 3, Personnel Safety; Subgroup B, Occupational Illness/Injury, Off-normal.

- Group 7, Value Basis Reporting, Off-normal.

For the purposes of the MK-Ferguson Company Occurrence Reporting and Processing System (ORPS) Program Manual, the Albuquerque Project Office (APO) Facility Manager shall recommend occurrence categorization to the appropriate DOE personnel.

Occurrence categorization shall be as follows:

Group 1. Facility Condition

Group 2. Environmental

Group 3. Personnel Safety

Group 4. Personnel Radiation Protection

Group 5. Safeguards and Security

Group 6. Transportation

Group 7. Value Basis Reporting

Group 8. Facility Status

Group 9. Cross-Category Items 


\section{GROUP 1. FACILITY CONDITION}

\section{A. Nuclear criticality safety}

Items in this subgroup, as defined in DOE Order 5000.3B, do not apply to UMTRA Project operations. Operations are limited to handling residual ore materials with no possibility of nuclear criticality.

\section{B. Fires/explosions}

$\rightarrow$

\section{Emergency}

- Any occurrence causing uncontrolled release of radioactive or hazardous material to the environment that could result in significant off-site consequences.

\section{Off-normal}

- Any unplanned fire in a facility that takes longer than 10 minutes to extinguish after the arrival of fire protection personnel.

C. Any unplanned occurrence resulting in serious degradation of the safety status or the analytical basis of a facility or process

\section{Unusual}

- Any occurrence outside the design basis or the safety analysis of the facility/process.

- Any occurrence preventing immediate facility or off-site emergency response capabilities.

\section{Off-normal}

- Any occurrence leading the contractor to limit facility operations. The limits may be either self-imposed or based on procedural requirements.

D. Loss of control of radioactive material/spread of radioactive contamination

\section{Unusual}

- Identification of removable or fixed radioactive contamination with activity exceeding the appropriate limits specified in Table 2-4 of the DOE Radiological 
Control Manual in any nonradiologically controlled area, excluding designated haulage routes.

\section{Off-normal}

- Any unplanned spill of liquids off the site or in nonradiologically controlled areas that meets the following conditions:

- The amount of liquid exceeds 1 gallon.

- The liquid is contaminated with radioactive material in concentrations greater than the Derived Concentration Guide (DCG) values listed in DOE Order 5400.5, Figure III-1.

- The liquid is not already classified and reported in conjunction with other requirements of this order.

E. A deficiency such that a structure, system, or component vital to safety or program performance does not conform to stated criteria and cannot perform its intended function

\section{Unusual}

- A reportable occurrence caused by a defective item or service.

F. Violation of procedures (including maintenance requirements and system lineups) or inadequate procedures, either of which result in adverse effects on performance, safety, or reliability

\section{Off-normal}

- Any violation of facility procedures that results in actual equipment damage to DOE property in excess of $\$ 1000$.

- Unplanned deviation from written procedures that results in adverse effects on performance, safety, or reliability.

\section{G. Unsatisfactory surveillance/inspections}

Items in this subgroup do not apply to UMTRA Project operations because reference is made to Class $A$ and $B$ safety equipment not used on the UMTRA Project. 
H. Any deficiency in a structure, system, component, or facility vital to program continuity that, to redesign or repair or otherwise establish the adequacy of the item, will result in significant program delay or cost

- Items in this subgroup shall be categorized as Off-normal, Unusual, or Emergency as appropriate, depending on the severity of the occurrence results.

\section{Operations}

\section{Emergency}

- Loss of any primary confinement/containment that results in uncontrolled hazardous material/energy release.

- Dangerous weather conditions/natural phenomena capable of breaching facility structures.

- Any request to an off-site authority for emergency cssistance that results from the activation of an emergency/contingency operation or plan for an occurrence meeting the emergency categorization criteria in this document.

\section{Unusual}

- Natural phenomena (for example, earthquake, flood, or tornado) other than those occurrences in Group 8, Facility Status, that seriously disrupt facility activities.

- Any evacuation of an entire facility in response to an actual occurrence.

- Any occurrence requiring off-site radiological assistance.

\section{Off-normal}

- Any unplanned outages of service systems (for example, cooling water, electrical, phones, or communication systems) or unexpected consequences from a planned outage that disrupt normal facility operations for more than 48 hours.

- Any facility evacuation (excluding office space) conducted as a precautionary measure (for example, in the event of a fire).

J. Inadequate experiment/test performance resulting in significant program delay or cost. Significant program delays should take into account the time required to 
repeat the test tc obtain any necessary data, while cost considerations should weigh the cost of repeat testing, any damage, and cleanup.

Items in this subgroup do not apply to UMTRA Project operations. Experiments or tests supporting UMTRA Project operations do not have the potential for significant delays or costs. 


\section{GROUP 2. ENVIRONMENTAL}

\section{A. Radionuclide releases}

\section{Unusual}

- Release of a radionuclide material that exceeds a federally permitted release by the amount of a Comprehensive Environmental Response, Compensation, and Liability Act (CERCLA) Reportable Quantity (RQ); when no federally permitted release exists, the release exceeds the RO.

- Release of a radionuclide material that violates environmental requirements in federal permits, federal regulations, or DOE standards.

- Releases requiring an immediate report (within 4 hours) to federal regulatory authorities or triggering specific action levels for an outside federal agency.

\section{Off-normal}

- Any release of radionuclide material to uncontrolled areas that is not part of a normal monitored release and exceeds 50 percent of a CERCLA RO for such material, as specified in 40 CFR Part 302.

- Any haulage spill of uranium mill tailings to nonradiologically controlled areas that exceeds 15 pounds as specified in Department of Transportation (DOT) exemption DOT-E 10594.

\section{NOTE}

Tailing spills of 15 pounds or less that result in an identifiable pile of material on the road or that involve spots or stains above the levels given in Table 2-2 of the DOE Radiological Control Manual (more than $1000 \mathrm{dpm} / 100 \mathrm{~cm}^{2}$ alpha; $1000 \mathrm{dpm} / 100 \mathrm{~cm}^{2}$ beta-gamma) will not be reported to the DOE through the ORPS system. However, these spills, spots, and stains shall continue to be reported to the APO using the Site Notification Report. Site Notification Reports for tailing spills of less than 15 pounds and spots or stains with activity exceeding the levels given in Table 2-2 shall be submitted to the APO within 24 hours, not to exceed 80 hours following the occurrence to allow for weekends and holidays. Weekly reports will be provided to the DOE UMTRA Project Office. Site Notification Reports shall be maintained in the ORPS nonreportable files. 
- Any controlled release of radionuclide material that occurs as a monitored part of normal operations but exceeds what historical data and/or analysis show is expected as a result of normal operations.

- Any monitored facility or site boundary where exposure or concentrations exceed what historical data and/or analysis show is expected as a result of normal operations.

- Any detection of a radionuclide in a sanitary or storm sewer, waste or process stream, or any holding points where such a material is not expected.

- Any controlled, uncontrolled, or accidental release not classified as an Unusual occurrence but that will be reported in writing to state/local agencies in a format other than routine monthly or quarterly reports.

\section{B. Release of hazardous substances/regulated pollutants/oil}

Throughout this document and particularly within this subgroup, reporting of spills or releases of ethylene glycol and glycol ethers shall be limited to spills or releases that exceed 100 pounds.

\section{Emergency}

- Any actual or potential release of material to the environment that results in or could result in significant off-site consequences (for example, the need to relocate people, major wildlife kills, major wetland degradation, or major aquifer contamination).

- Any release of hazardous substances or regulated pollutants in concentrations exceeding five times the respective RQs specified for such materials in 40 CFR Part 302.

\section{Unusual}

- Release of a hazardous substance or regulated pollutant exceeding a CERCLA $R O$, as specified in 40 CFR Part 302, or exceeding a federally permitted release by an RO.

- Release of a hazardous substance, regulated pollutant, or oil or other petroleum product that violates environmental requirements in federal permits, federal regulations, or DOE standards.

- Release below emergency levels that requires immediate reporting (within 4 hours) to federal regulatory agencies or triggers specific action levels for an outside federal agency. 
- Any release of 100 or more gallons of oil or other petroleum product to the ground or to surface or ground water outside of a spill containment area.

\section{Off-normal}

- Release of a hazardous substance or regulated pollutant to controlled or uncontrolled areas that is not part of a normal, monitored release and that exceeds 50 percent of a CERCLA RO for such material, as specified in 40 CFR Part 302.

- Any release of oil or other petroleum product greater than 10 gallons but less than 100 gallons to the ground or to ground or surface water outside of a spill containment area.

- Any detection of a toxic or hazardous substance in a sanitary or storm sewer, waste or process stream, or any holding points where such a material is not expected.

- Any controlled, uncontrolled, or accidental release not classified as an unusual occurrence but that will be reported in writing to state/local agencies in a format other than routine monthly or quarterly reports.

- Any controlled release of hazardous/regulated material that occurs as a monitored part of normal operations but exceeds what historical data and/or analysis shows is expected as a result of normal operations.

- Any general environmental monitoring where concentration increases to a level exceeding what historical data and/or analysis shows is expected as a result of normal operations.

\section{Discovery of hazardous material contamination due to DOE operations}

\section{Emergency}

- Discovery of contamination that results or could result in significant consequences (for example, exceeding safe exposure limits to workers or public).

- Discovery of on-site or off-site hazardous material contaminations in concentrations exceeding five times the respective ROs for such materials, as specified in 40 CFR Part 302. 


\section{Unusual occurrence}

- Discovery of on-site or off-site contamination due to DOE operations that does not represent an immediate threat to the public but exceeds a reportable quantity for such materials, as specified in 40 CFR Part 302.

- Any discovery of ground water contamination that is not part of an existing plume or previously identified in either an annual report or in any CERCLA/Resource Conservation and Recovery Act (RCRA) activity or report.

\section{Off-normal}

- Discovery of on-site contamination attributable to DOE operations that exceeds 50 percent of a reportable quantity for such material, as specified in $40 \mathrm{CFR}$ Part 302.

\section{Ecological resources}

\section{Unusual}

- Any occurrence causing significant impact to any ecological resource for which the DOE is a trustee (for example, destruction of a critical habitat, damage to a historic/archeological site, or damage to wetlands).

\section{E. Agreement/compliance activities}

\section{Unusual}

- Any agreement, compliance, remediation, or permit-mandated activity for which formal notification has been received from the relevant regulatory agency that a site plan is not satisfactory or that a site is considered in noncompliance with schedules or requirements.

- Any occurrence under any agreement or compliance area that requires notification of an outside regulatory agency within 4 hours or triggers an outside regulatory agency action level, or otherwise indicates specific interest/concern from such agencies.

\section{Off-normal}

- Any occurrence under any agreement or compliance area that will be reported in writing to outside agencies in a format other than routine monthly or quarterly reports. 


\section{GROUP 3. PERSONNEL SAFETY}

\section{A. Occupational illness/injuries}

\section{Unusual}

- Any occurrence due to DOE operations that results in fatality or terminal injury or illness.

- Any occurrence resulting in five or more hospitalization cases, as defined by 29 CFR Part 1904.

\section{Off-normal}

- Any occupational illness or injury resulting in inpatient hospitalization.

\section{B. Vehicular incidents}

This subgroup covers vehicular transportation incidents. Group 6 also should be considered for reporting. Transportation incidents without injury (for example, those involving hazardous or radioactive material or financial loss) must be reported in accordance with the Group 6 requirements.

\section{Unusual}

- Any vehicular incident resulting in fatality, injury, or illness classified under Group 3, Subgroup A, Unusual.

- Any vehicle incident involving departmental property, with fatality(ies) to a person(s) other than DOE personnel or DOE contractor personnel.

\section{Off-normal}

- Any vehicular incident with injury(ies) involving departmental property that results in a lost workday case.

- Any vehicular incident involving departmental property, with injury(ies) to a person(s) other than DOE personnel or DOE contractor personnel. 


\section{Miscellaneous}

\section{Unusual}

- Personnel exposures to hazardous chemicals in excess of appropriate occupational safety limits.

\section{Off-normal}

- Unauthorized use of flammable, toxic, explosive, corrosive, or other unsafe or dangerous processes, chemicals, materials, or methods previously prohibited.

- Any shutdown of a work activity resulting from an Occupational Safety and Health Act (OSHA) violation involving a condition or practice of imminent danger as defined in the OSHA of 1970 (for example, trenching without adequate shoring or working at levels without fall protection). 


\section{GROUP 4. PERSONNEL RADIATION PROTECTION}

\section{A. External radiation exposure}

Unless specified otherwise, all doses stipulated in the following requirements are calculated as the sum of the committed effective dose equivalent from radionuclides taken into the body (internal exposure) and the dose equivalent from external exposure.

\section{Unusual}

- Exposure of any member of the public to external radiation fields that, in conjunction with any internal exposures, results in a dose exceeding the annual limits given in Table 2-1 of the DOE Radiological Control Manual (for on-site exposures) or DOE Order 5400.5, Chapter II, Paragraph 1 (for off-site exposures).

\section{Off-normal}

- Exposure of any minor or student on the site to external radiation fields that, in conjunction with any internal exposures, results in a dose exceeding 25 percent of the annual limits given in Table 2-1 of the DOE Radiological Control Manual.

- Exposure of any member of the public to external radiation fields that, in conjunction with any internal exposures, results in a dose exceeding 25 percent of the annual limits given in Table 2-1 of the DOE Radiological Control Manual (for on-site exposures) or DOE Order 5400.5, Chapter II, Paragraph 1 (for offsite exposures).

\section{B. Personnel contamination}

\section{Unusual}

- Any occurrence resulting in five or more individual coritamination cases.

- Any occurrence requiring off-site medical assistance for contaminated personnel.

- Identification of radioactive contamination on personnel or clothing off the site.

\section{Off-normal}

- Identification of radioactive contamination on personnel or clothing outside a facility controlled area. 
- Any measurement of personnel or clothing contamination (excluding protective clothingl, measured in accordance with Article 338 of the DOE Radiological Control Manual (prior to washing or decontamination), with activity exceeding $5000(\mathrm{dpm})$ beta/gamma/100 $\left(\mathrm{cm}^{2}\right)$ or $500 \mathrm{dpm}$ alpha/100 $\mathrm{cm}^{2}$, excluding radon-222 and associated daughter products.

\section{Internal exposure}

\section{Off-normal}

- Any confirmed intake of radioactive material by a worker that would result in a committed effective dose equivalent from all intakes equal to or greater than 0.1 rem.

- Any confirmed intake of radioactive material by a minor or student on the site that would result in a committed effective dose equivalent equal to or greater than 10 percent of the annual limit specified in Table 2-1 of the DOE Radiological Control Manual.

- Any confirmed intake of radioactive material by a member of the public that would result in a committed effective dose equivalent equal to or greater than 10 percent of the annual limit specified in Table 2-1 of the DOE Radiological Control Manual. 


\section{GROUP 5. SAFEGUARDS AND SECURITY}

Occurrences in this group will require consideration of classification as well as addition to careful review for privacy considcrations. DOE management recognizes the lack of detail that may be required in such reports.

\section{A. Criminal acts}

\section{Emergency}

- Occurrences regarding the following:

- Bomb-related incidents: detonation, location of actual device, or suspicious device resulting in a credible bomb threat.

- An actual sabotage event or credible sabotage threat.

- An actual terrorist attack or credible terrorist threat.

- Extortion/kidnapping of DOE or DOE contractor personnel.

\section{Unusual}

- Violent assault/battery, murder, or unjustified use of deadly force on DOE property.

- Theft/diversion of government property (for property valued greater than $\$ 100,000)$.

- Racketeering or other organized criminal activity on the site.

\section{Off-normal}

- Occurrences regarding the following:

- Location of a suspicious device or a noncredible bomb threat.

- Noncredible terrorist threat.

- Noncredible sabotage threat.

- Theft/diversion of government property (for property valued between $\$ 10,000$ and $\$ 100,000)$. 
- On-site felony conspiracies (for example, blackmail, fraud, embezzlement, extortion or forgeryl not involving classified information.

B. Loss of control of classified matter

Items in this subgroup do not apply because reference is made to classified information/materials that are not part of UMTRA Project operations.

\section{Substance abuse}

\section{Unusual}

- Possession of controlled/illegal substance(s) with intent to distribute on the site.

- Any reportable occurrence on the site at least partially attributed to the use of illegal drugs or alcohol.

\section{Off-normal}

- On-site discovery of the use, possession, or involvement of illegal drugs by DOE or DOE contractor personnel.

\section{Foreign intelligence activities}

\section{Unusual}

- Espionage, foreign intelligence activities, treason, or subversive activities by or directed at DOE or DOE contractor personnel.

\section{Off-normal}

- DOE or DOE contractor personnel who believe they might be the target of attempted exploitation by a foreign entity.

\section{E. Computer equipment/systems}

Item:s in this subgroup do not apply to UMTRA Project operations. Computer systems do not contain classified data nor is their use related to security features or the possibility of facility operations disruption.

F. Unplanned/unscheduled outage of site security system

Items in this subgroup do not apply to UMTRA Project operations. Site security systems are limited to nonsubstantial perimeter fences not consistent with the type of security systems contemplated by DOE Order 5300.3B. 


\section{G. Demonstrations/protests}

\section{Unusual}

- Disruptive activities impeding vehicular or employee access/egress.

- Attempted or actual trespass with malicious intent.

- Malevolent activities causing property damage or bodily harm.

\section{Off-normal}

- Lawful activities warranting deployment of additional protective measures.

\section{H. Firearms}

\section{Unusual}

- Unauthorized firearm discharge resulting in personnel injury.

\section{Off-normal}

- Unauthorized firearm discharge resulting in no personnel injury.

I. Other security concerns

\section{Off-normal}

- On-site malicious mischief, disorderly conduct, or vandalism disrupting plant activity or causing damage between $\$ 10,000$ and $\$ 100,000$.

\section{J. Material control and accountability}

\section{Unusual}

- Loss of accountability of a radioactive source that exceeds the lesser value of exempt quantities, as specified in DOE Notice N5400.9 (Sealed Radioactive Source Accountability) or state standards/regulations.

- Loss or apparent loss of accountability of a radioactive source whenever a state, local government, or other federal agency must be notified. 


\section{GROUP 6. TRANSPORTATION}

Shippers are responsible for occurrences involving their shipments. DOE organizations receiving hazardous materials not in compliance with appropriate requirements from a DOE shipper must report the discrepancies to the DOE shipper. The DOE shipper will prepare Notification and Occurrences Reports in accordance with this order and implement suitable corrective actions. If an out-of-compliance shipment is received from a non-DOE shipper, the DOE recipient shall notify the non-DOE shipper of the discrepancy and shall prepare Notification and Occurrence Reports in accordance with DOE Order 5000.3B. These reports must contain a statement that the non-DOE shipper has been notified and must identify any corrective actions taken or planned to prevent the occurrence from being repeated.

The term "limited quantity" as used in this group is defined in 49 CFR $\$ 171.8$ as "the maximum amount of a hazardous material for which there is a specific labeling or packaging exception."

\section{A. Off-site transportation (DOT jurisdiction)}

\section{Unusual}

- An off-site transportation event involving the release of hazardous material las specified in 49 CFR $\$ 171.8$ ), other than radioactive material, in an amount exceeding a limited quantity (as specified in 49 CFR \$171.8) transported in support of DOE operations.

- Any radioactive material shipment transported off the site that arrives at its destination with radiation or contamination levels exceeding DOT-allowable limits.

- Any shipment of radioactive material or hazardous waste that arrives at its destination with a nonreconci' ble shipping paper discrepancy or unaccounted for package (for example, actual number of packages inconsistent with number indicated on shipping papers) related to material quantity.

- Any violation of DOT Federal Motor Carrier Safety Regulations that contributes to a transportation event involving the release of hazardous material.

\section{Off-normal}

- An off-site transportation event involving the release of hazardous material (as specified in 49 CFR $\$ 171.8$ ), other than radioactive material, not exceeding a limited quantity (as specified in 49 CFR \$171.8) transported in support of departmental operations. 
- Any other violation of regulatory requirements involving improper material description, marking, labeling, placarding, routing, or separation/segregation of hazardous materials that could or does result in the following:

- Improper handling/storage.

- Personnel exposures higher than permitted.

- Emergency response actions inconsistent with the actual hazard.

- Any occurrence resulting from a violation of DOT Federal Motor Carrier Safety Regulations for safe truck operation.

- Evidence of improper classification of hazardous materials transported off the site.

- Evidence of improper selection or assembly of a hazardous material package transported off the site.

- Transportation activities performed by unqualified personnel.

- Any transportation event involving departmental property that results in vehicular damage of more than $\$ 5000$ or, for insurance purposes, damage considered a total loss.

\section{B. On-site transportation (DOE jurisdiction)}

\section{Unusual}

- An on-site transportation event involving the release of a reportable quantity of a hazardous substance (as specified in 49 CFR \$171.8), excluding releases of uranium mill tailings to radiologically controlled areas when the tailings are transported in support of departmental operations.

- An on-site transportation event involving the release of radioactive material exceeding an expected quantity (as specified in 49 CFR $\$ 173.421-1$ [a]), excluding releases of uranium mill tailings to radiologically controlled areas when the tailings are transported in support of departmental operations.

- Any on-site transportation event involving the release of hazardous material las specified in 49 CFR $\$ 171.8$ ), other than radioactive material, exceeding a limited quantity (as specified in 49 CFR $\$ 171.8$ ) transported in support of departmental operations. 


\section{Off-normal}

- Any on-site transportation event involving the release of hazardous material las specified in 49 CFR $\$ 171.8$ ), other than radioactive material, not exceeding a limited quantity (as specified in 49 CFR \$171.8) transported in support of departmental operations.

- Any on-site transportation event involving the release of radioactive material not exceeding an expected quantity (as specified in 49 CFR \$173.421-1/a]), excluding releases of uranium mill tailings to radiologically controlled areas and transported in support of departmental operations.

- Any violation of DOE requirements involving improper material description, marking, labeling, placarding, routing, or separation/segregation of hazardous materials that could result in the following:

- Improper handling/storage.

- Personnel exposures higher than permitted.

- Emergency response actions inconsistent with the actual hazard.

- Any transportation event involving departmental property that results in vehicular damage of more than $\$ 5000$ or, for insurance purposes, damage considered a total loss. 


\section{GROUP 7. VALUE BASIS REPORTING}

Any occurrence specifying cost as a basis for reporting, unless otherwise stated, shall be classified by the following monetary values necessary to repair, replace, or otherwise restore a facility/system/component to acceptable operation. Costs used for reporting should be reasonable initial estimates.

\section{Unusual}

- Estimated loss or damage to DOE or other property that amounts to $\$ 100,000$ or more, or estimated costs of $\$ 100,000$ or more required for cleaning (including decontamination), renovating, replacing, or rehabilitating structures, equipment, or property.

\section{Off-normal}

- Estimated loss or damage to DOE or other property that amounts to between $\$ 10,000$ and $\$ 100,000$ (for vehicles the lower limit is $\$ 5000$ or, for insurance purposes, damage considered a total loss) or estimated costs within these limits required for cleaning (including decontamination), renovating, replacing, or rehabilitating structures, equipment, or property.

\section{NOTE}

Damage or loss of privately owned property is not reportable under the requirements of this subgroup except to the extent that the DOE is liable for damage and loss consequences resulting from the occurrence. 


\section{GROUP 8. FACILITY STATUS}

A. Any unplanned occurrence in any portion of a program conducted in accordance with approved requirements and procedures that results in the facility, process, or activity being secured or operations being significantly curtailed.

\section{Unusual}

- Any unscheduled shutdown, other than weather-induced (see note below), of 1 week or longer.

\section{Ui: inormal}

- Any unscheduled shutdown, other than weather-induced (see note below), of a facility, process, or operation longer than 2 days.

B. Any unplanned occurrence extending the shutdown of a current facility, process, or activity.

\section{Unusual}

- Any increase in shutdown schedule that exceeds 50 percent of the planned schedule at the time of extension or 1 month (see note below).

C. Any unplanned occurrence delaying the start-up of a new facility, process, or activity

\section{Unusual}

- Any delay in start-up schedule of 12 weeks or longer (see note below).

\section{Off-normal}

- Any delay in start-up schedule of 1 merith or longer (see note below).

\section{NOTE}

If shutdowns attributed to natural weather conditions are within times that historical data show are expected and the shutdowns are considered in the site schedule for that season, shutdowns will not be considered unscheduled and will therefore not be reported through the ORPS system. However, all shutdowns not meeting these criteria will be reported. Examples include an excessive number of shutdowns; shutdowns caused by unusual or unexpected conditions; or sites that shut down for a time exceeding what historical data show is expected. 


\section{GROUP 9. CROSS-CATEGORY ITEMS}

A. A series of related occurrences that individually do not warrant reporting under the preceding criteria, but that collectively are considered significant enough to warrant reporting

B. A near-miss to one of the reporting classifications under the preceding categories

\section{Unusual}

- An occurrence wherein the conditions needed to cause an Unusual occurrence existed (for example, all barriers to event initiation were compromised).

\section{Off-normal}

- An occurrence wherein the conditions needed to cause a reportable occurrence were prevented from existing by one remaining barrier after other barriers had been compromised (for example, one additional independent failure/degradation was necessary for event initiation).

C. Identification of potential concerns or issues deemed worthy of reporting. 


\subsection{REPORTABLE OCCURRENCES FOR INACTIVE SITES}

Occurrences are arranged into nine groups relating to U.S. Department of Energy (DOE) Uranium Mill Tailings Remedial Action (UMTRA) Project operations for inactive sites. These nine groupings are provided for reference to determine whether an occurrence meets reporting requirement criteria in accordance with the minimum reporting requirements contained in Attachment 1 of DOE Order 5000.3B. Event groups and significance categories that cannot or will not occur, and that do not apply to UMTRA Project operations, are omitted.

Up to three groups may be used to describe the nature of the occurrence. All groups that pertain to the occurrence should be identified.

When an occurrence meets the criteria for more than one group, the category of occurrence (Emergency, Unusual, or Off-normall selected should be based upon the severity of the occurrence results.

Occurrence categorization shall be as follows:

Group 1. Facility Condition

Group 2. Environmental

Group 3. Personnel Safety

Group 4. Personnel Radiation Protection

Group 5. Safeguards and Security

Group 6. Transportation

Group 7. Value Basis Reporting

Group 8. Facility Status

Group 9. Cross-Category Items 


\section{GROUP 1. FACILITY CONDITION}

\section{A. Nuclear criticality safety}

Items in this subgroup, as defined in DOE Order 5000.3B, do not apply to UMTRA Project operations.

E. Fires/explosions

\section{Emergency}

- Any occurrence causing uncontrolled release to the environment of radioactive / or hazardous material that could result in significant off-site consequences.

- Any occurrence not under control causing more than minor damage and loss of building integrity.

\section{Off-normal}

- Any unplanned fire in a facility that takes longer than 10 minutes to extinguish after the arrival of fire protection personnel.

C. Any unplanned occurrence resulting in serious degradation of the safety status or the analytical basis of a facility or process

\section{Unusual}

- Any occurrence outside the design basis of the facility/process.

- Any occurrence preventing immediate facility or off-site emergency response capabilities.

\section{Off-normal}

- Any occurrence leading the contractor to limit facility operations. The limits may be either self-imposed or based on procedural requirements.

D. Loss of control of radioactive material/spread of radioactive contamination

\section{Unusual}

- Identification of radioactive contamination off the site with activity exceeding the surface radioactivity levels specified in DOE Order 5400.5, Figure IV-1, that 
have not been previously identified in a DOE annual reporc or in any CERCLA/RCRA activity/report.

\section{Off-normal}

- Any unplanned spill of liquids that meets the iollowing conditions:

- The amount of liquid exceeds 1 gallon.

- The liquid is contaminated with radioactive material in concentrations greater than the DCG values listed in DOE Order 5400.5, Figure III-1.

- The liquid is not already classified and reported in conjunction with other requirements of this order.

E. A deficiency such that a structure, system, or component vital to safety or program performance does not conform to stated criteria and cannot perform its intended function

\section{Unusual}

- A reportable occurrence caused by a defective item or service.

F. Violation of procedures (including maintenance requirements and system lineups) or inadequate procedures, either of which result in adverse effects on performance, safety, or reliability

\section{Off-normal}

- Any violation resulting in actual equipment damage exceeding $\$ 1000$.

- Deviation from written procedures that results in adverse effects on performance, safety, or reliability.

\section{G. Unsatisfactory surveillance/inspections}

Items in this subgroup do not apply to UMTRA Project operations because reference is made to Class $A$ and $B$ safety equipment not used in support of the UMTRA Project.

H. Any deficiency in a structure, system, component, or facility vital to program continuity that, to redesign or repair or otherwise establish the adequacy of the item, will result in significant program delay or cost. The severity of this category depends upon the severity of the occurrence results(s). 


\section{Operations}

\section{Emergency}

- Loss of any primary confinement/containment that results in uncontrolled hazardous material/energy release.

- Dangerous weather conditions/natural phenomena capable of breaching facility structures.

- Any request to an off-site authority for emergency assistance that results from the activation of an emergency/contingency operation or plan.

\section{Unusual}

- Any evacuation of an entire facility (excluding office space) in response to an actual occurrence.

- Weather conditions/natural phenomena causing serious disruptions of facility activity.

- Any occurrence requiring off-site radiological assistance.

\section{Off-normal}

- Any facility evacuation (excluding office space) conducted as a precautionary measure (for example, in the event of a fire).

J. Inadequate experiment/test performance resulting in significant program delay or cost. Significant program delays should take into account the time required to repeat the test to obtain necessary data while cost considerations should weigh the costs of repeat testing, damage, and cleanup.

Items included in this subgroup will be categorized off-normal, unusual, or emergency as appropriate, depending on the severity of the occurrence results. 


\section{GROUP 2. ENVIRONMENTAL}

\section{A. Radionuclide roleases}

\section{Unusual}

- Release of a radionuclide material that exceeds a federally permitted release by the amount of a CERCLA RO, or when no federally permitted release exists, the release exceeds the RQ.

- Release of a radionuclide material that violates environmental requirements in federal permits, federal regulations, or DOE standards.

- Releases requiring an immediate report (within 4 hours) to federal regulatory authorities or that triggers specific action levels for an outside federal agency.

\section{Off-normal}

- Any release of radionuclide material to controlled or uncontrolled areas that is not part of a normal monitored release and exceeds 50 percent of a CERCLA RO specified for such material, as specified in 40 CFR Part 302.

- Any controlled release of radionuclide material that occurs as a monitored part of normal operations but exceeds what historical data and/or analysis show is expected as a result of normal operations.

- Any monitored facility or site boundary where exposure or concentrations exceed what historical data and/or analysis show is expected as a result of normal operations.

- Any detection of a radionuclide in a sanitary or storm sewer, waste or process stream, or holding point where such a material is not expected.

- Any controlled, uncontrolled, or accidental release not classified as an Unusual occurrence but that will be reported in writing to state/local agencies in a format other than routine monthly or quarterly reports. 


\section{B. Release of hazardous substances/regulated pollutants/oil}

Throughout this document and particularly within this subgroup, reports of spills or releases of ethylene glycol and glycol ethers shall be limited to spills or releases exceeding 100 pounds.

\section{Unusual}

- Release of a hazardous substance or regulated pollutant that exceeds a CERCLA RO, as specified in 40 CFR Part 302, or exceeding a federally permitted release by an RQ.

- Release of a hazardous substance, regulated pollutant oil, or other petroleum product that violates environmental requirements in federal permits, federal regulations, or DOE standards.

- Release below emergency levels that requires an immediate reporting (within 4 hours) to federal regulatory agencies or triggers specific action levels for an outside federal agency.

- Any release of 100 or more gallons of oil or other petroleum product to the ground, or to surface or ground water.

\section{Off-normal}

- Release of a hazardous substance or regulated pollutant to controlled or uncontrolled areas that is not part of a normal, monitored release and that exceeds 50 percent of a CERCLA RO for such material, as specified in 40 CFR Part 302.

- Any release of oil greater than 10 gallons but less than 100 gallons.

- Any detection of a toxic hazardous substance in a sanitary or storm sewer, waste or process stream, or any holding point where such material is not expected.

- Any controlled, uncontrolled. or accidental release that is not classified as an Unusual Occurrence but reported in writing to state/local agencies in a format other than routine monthly or quarterly reports.

- Any controlled release of hazardous/regulated material that occurs as a monitored part of normal operations but exceeds what historical data and/or analysis shows is expected as a result of normal operations. 
- Any general environmental monitoring where concentration increases to a level exceeding what historical data and/or analysis shows is expected as a result of normal operations.

C. Discovery of hazardous material contamination due to DOE operations

\section{Unuaual}

- Discovery of on-site or off-site contamination from DOE operations that does not represent an immediate threat to the public but exceeds the reportable quantity for such materials, as specified in 40 CFR Part 302.

- Any discovery of ground water contamination that is not part of an existing plume previously identified in either an annual report or in any CERCLA/RCRA activity or report.

\section{Off-normal}

- Discovery of on-site contamination attributable to DOE operations that exceeds 50 percent of a reportable quantity for such material, as specified in 40 CFR Part 302.

D. Ecological resources

\section{Unusual occurrence}

- Any occurrence causing significant impact to any ecological resource for which the DOE is a trustee (for example, destruction of a critical habitat, damage to a historical/archeological site, or damage to wetlands).

E. Agreement/compliance activities

\section{Unusual}

- Any agreement, compliance, remediation, or permit-mandated activity for which formal notification has been received from the relevant regulatory agency that a site plan is not satisfactory or that a site is considered in noncompliance with schedules or requirements.

- Any occurrence under any agreement or compliance area that requires notification of an outside regulatory agency within 4 hours, triggers an outside regulatory agency action level, or otherwise indicates specific interest/concern from such agencies. 


\section{Off-normal}

- Any occurrence under any agreement or compliance area that will be reported in writing to outside agencies in a format other than routine monthly or quarterly reports. 


\section{GROUP 3. PERSONNEL SAFETY}

\section{A. Occupational illness/injuries}

\section{Unusual}

- Any occurrence caused by DOE operations that results in a fatality or terminal injury or illness.

- Any one occurrence that results in five or more hospitalization cases, as defined by 29 CFR Part 1904.

\section{Off-normal}

- Any occupational illness or injury resulting in inpatient hospitalization.

\section{B. Vehicular incidents}

This section covers vehicular transportation incidents including DOE or DOE contractor-operated aircraft. Group 6 should also be considered in reporting. Transportation incidents without injury (for example, those involving hazardous or radioactive material or financial loss) must be reported in accordance with Group 6 requirements.

\section{Emergency}

- Inflight aircraft occurrence involving a hijacking or bomb threat that may compromise the health and safety of the aircraft, its occupants, or the general public.

\section{Unusual}

- Any vehicular incident resulting in fatality, injury, or illness classified under Group 3, Subgroup A, Unusual.

- Any vehicle incident involving departmental property with fatality(ies) to a person(s) other than DOE personnel or DOE contractor personnel.

\section{Off-normal}

- Any vehicular incident with injury(ies) involving departmental property that results in a lost workday case. 
- Any vehicular incident involving departmental property, with injury(ies) to a person(s) other than DOE personnel or DOE contractor personnel.

\section{Miscellaneous}

\section{Unusual}

- Personnel exposure to hazardous chemicals exceeding appropriate occupational safety limits.

\section{Off-normal}

- Unauthorized use of flammable, toxic, explosive, corrosive, or other unsafe or dangerous processes, chemicals, materials, or methods previously prohibited.

- Any shutdown of a work activity resulting from an OSHA violation involving a condition or practice of imminent danger as defined in the OSHA of 1970 (for example, trenching without adequate shoring or working at levels without fall protection). 


\section{GROUP 4. PERSONNEL RADIATION PROTECTION}

\section{A. External radiation exposure}

Unless specified otherwise, all doses stipulated in the following requirements are calculated as the sum of the committed effective dose equivalent from radionuclides taken into the body (internal exposure) and the dose equivalent from external exposure.

\section{Off-normal}

- Unplanned single exposure of any occupational worker to external radiation fields which, in conjunction with any internal exposures, results in a dose exceeding an established facility administrative limit or exceeding 10 percent of the annual limits given in Table 2-1 of the DOE Radiological Control Manual, whichever is less.

- Exposure of any minor student on the site to external radiation fields that, in conjunction with any internal exposures, results in a dose exceeding 25 percent of the annual limits given in Table 2-1 of the DOE Radiological Control Manual.

- Exposure of any member of the public to external radiation fields that, in conjunction with any internal exposures, results in a dose exceeding 25 percent of the annual limits given in Table 2-1 of the DOE Radiological Control Manual (for on-site exposures) or DOE Order 5400.5, Chapter II, Paragraph 1 (for offsite exposures).

B. Personnel contamination

\section{Unusual}

- Any occurrence resulting in five or more individual contamination cases.

- Any occurrence requiring off-site medical assistance for contaminated personnel.

- Identification of radioactive contamination on personnel or clothing off the site.

\section{Off-normal}

- Identification of radioactive contamination on personnel or clothing outside a facility controlled area. 
- Any measurement of personnel or clothing contamination (excluding protective clothingl measured in accordance with Article 338 of the DOE Radiological Control Manual (prior to washing or decontamination), with activity exceeding $5000 \mathrm{dpm}$ beta/gamma/100 $\mathrm{cm}^{2}$.

\section{Internal exposure}

\section{Off-normal}

- Any confirmed intake of radioactive material by a worker that would result in a committed effective dose equivalent from all intakes equal to or greater than 0.1 rem.

- Any confirmed intake of radioactive material by a minor or student on the site that would result in a committed effective dose equivalent equal to, or greater than 10 percent of the annual limited specified in Table 2-1 of the DOE Radiological Control Manual.

- Any confirmed intake of radioactive material by a member of the public that would result in a committed effective dose that is equivalent equal to, or greater than 10 percent of the annual limit specified in Table 2-1 of the DOE Radiological Control Manual. 


\section{GROUP 5. SAFEGUARDS AND SECURITY}

Occurrences in this group will require careful review for privacy considerations. DOE management recognizes the lack of detail that may be required in such reports.

\section{A. Criminal acts}

\section{Emergency}

- Occurrences regarding the following:

- Bomb-related incidents: detonation, location of actual device, or suspicious device resulting in a credible bomb threat.

- An actual sabotage event or credible sabotage threat.

- An actual terrorist attack or credible terrorist threat.

- Extortion/kidnapping of DOE or DOE contractor personnel.

\section{Unusual}

- Violent assault/battery, murder, or unjustified use of deadly force on DOE property.

- Theft/diversion of government property (for property valued greater than $\$ 100,000)$.

- Racketeering or other organized criminal activity on the site.

\section{Off-normal}

- Occurrences regarding the following:

- Location of a suspicious device or noncredible bomb threat.

- Noncredible terrorist threat.

- Noncredible sabotage threat.

- Theft/diversion of government property (for property valued between $\$ 10,000$ and $\$ 100,000)$. 
- On-site felony conspiracies (for example, blackmail, fraud, embezzlement, extortion or forgery) not involving classified information.

\section{B. Loss of control of classified matter}

Items in this subgroup do not apply because reference is made to classified information/materials that are not part of UMTRA Project operations.

\section{Substance abuse}

\section{Unusual}

- Possession of controlled/illegal substance(s) with intent to distribute on the site.

- Any reportable occurrence on the site at least partially attributed to the use of illegal drugs or alcohol.

\section{Off-normal}

- On-site discovery of the use, possession, or involvement of illegal drugs by DOE or DOE contractor personnel.

D. Foreign intelligence activities

\section{Unusual}

- Espionage, foreign intelligence activities, treason, or subversive activities by or directed at DOE or DOE contractor personnel.

\section{Off-normal}

- DOE or DOE contractor personnel who believe they might be the target of attempted exploitation by a foreign entity.

\section{E. Computer equipment/systems}

Items in this subgroup do not apply to UMTRA Project operations at inactive sites.

F. Unplanned/unscheduled outage of site security system

Items in this subgroup, as defined in DOE Order 5000.3B, do not apply to the UMTRA Project's inactive sites. 


\section{G. Demonstration/protests}

\section{Unusual occurrence}

- Disruptive activities impeding vehicular or employee access/egress.

- Attempted or actual trespass with malicious intent.

- Malevolent activities causing property damage or bodily harm.

\section{Off-normal}

- Lawful activities warranting deployment of additional protective measures.

H. Firearms

\section{Unusual}

- Unauthorized firearm discharge resulting in personnel injury.

\section{Off-normal}

- Unauthorized firearms discharge resulting in no personnel injury.

I. Other security concerns

\section{Off-normal}

- Discovery of prohibited items within a protected area that are suspected of being positioned for the purpose of aiding and abetting a malevolent act or are of themselves illegal.

- On-site malicious mischief, disorderly conduct, or vandalism disrupting plant activity or causing damage between $\$ 10,000$ and $\$ 100,000$.

J. Material control and accountability

\section{Unusual}

- Loss or apparent loss whenever a state, local government, or other federal agency must be notified.

- Loss of accountability of a radioactive source that exceeds the lesser value of exempt quantities, as specified in DOE Notice N5400.9 (Sealed Radioactive Source Accountability) or state standards/regulations. 


\section{GROUP 6. TRANSPORTATION}

A. Off-site transportation (DOT jurisdiction) occurrences

\section{Unusual occurrence}

- An off-site transportation event involving the release of radioactive material transported in support of departmental operations.

- Any radioactive material shipment transported off the site that arrives at its destination with radiation or contamination levels exceeding DOT-allowable limits.

\section{Off-normal}

- Any other violation of regulatory requirements involving improper material description, marking, labeling, placarding, routing, or separation/segregation of hazardous material that could or does result in the following:

- Improper handling/storage.

- Personnel exposures higher than permitted.

- Emergency response actions inconsistent with the actual hazard.

- Evidence of improper classification of hazardous materials transported off the site.

- Evidence of improper selection or assembly of a hazardous material package transported off the site.

- Evidence that cargo has shifted during transport offsite.

- Transportation activities performed by unqualified personnel.

- Any transportation event involving departmental property that results in vehicular/aircraft damage of more than $\$ 5000$ or, for insurance purposes, damage considered a total loss.

\section{B. On-site transportation}

Items in this subgroup, as defined by DOE Order 5000.3B, do not apply to the UMTRA Project's inactive sites. 


\section{GROUP 7. VALUE BASIS REPORTING}

Any occurrence specifying cost as a basis for reporting, unless otherwise stated, will be classified by the following monetary values necessary to repair, replace, or otherwise restore a facility/system/component to acceptable operation. Costs used for reporting should be reasonable initial estimates.

\section{Unusual}

- Estimated loss or damage to DOE or other government property that amounts to $\$ 100,000$ or more, or estimated costs of $\$ 100,000$ or more required for cleaning (including decontamination), renovating, replacing, or rehabilitating structures, equipment, or property.

\section{Off-normal}

- Estimated loss or damage to DOE or other government property that amounts to between $\$ 10,000$ and $\$ 100,000$ (for vehicle/aircraft the lower limit is $\$ 5000$ or, for insurance purposes, is considered a total loss) or estimated costs within these limits required for cleaning (including decontamination), renovating, replacing, or rehabilitating structures, equipment, or property.

\section{NOTE}

Damage or loss of privately owned property is not reportable under the requirements of this group except to the extent that the DOE is liable for damage and loss consequences resulting from the occurrence. 


\section{GROUP 8. FACILITY STATUS}

Items in this group, as defined in DOE Order 5000.3B, do not apply to the UMTRA Project's inactive sites. 


\section{GROUP 9. CROSS-CATEGORY ITEMS}

A. A series of related occurrences that individually do not warrant reporting under preceding criteria, but that collectively are considered significant enough to warrant reporting.

The severity of this category depends upon the severity of the occurrence result(s).

B. A near-miss to one of the reporting classifications under the preceding categories

\section{Unusual}

- An occurrence wherein the conditions needed to cause an Unusual occurrence existed (for example, all barrier to event initiations were compromised).

\section{Off-normal}

- An occurrence wherein the conditions needed to cause a reportable occurrence were prevented from existing by one remaining barrier after other barriers had been compromised (for example, one additional independent failure/degradation was necessary for event initiation).

C. Identification of potential concerns or issues deemed worthy of reporting.

The severity of this category depends upon the severity of the occurrence result(s). 


\subsection{REPORTABLE OCCURRENCES FOR THE OFFICE ENVIRONMENT}

Occurrences are arranged into nine groups relating to U.S. Department of Energy (DOE) Uranium Mill Tailings Remedial Action (UMTRA) Project operations for active sites. These nine groupings are provided for reference to determine whether an occurrence meets reporting requirement criteria in accordance with the minimum reporting requirements contained in Attachment 1 of DOE Order 5000.3B. Event groups and significance categories that cannot or will not occur, and that do not apply to UMTRA Project operations, are omitted.

Up to three groups may be used to describe the nature of the occurrence. All groups that pertain to the occurrence shall be identified. An example of an occurrence with multiple categories would be the activation of a sprinkler system resulting in damage to 50 computers. In this instance, the occurrence would be categorized as follows:

- Group 1, Facility Condition, Subgroup B, Fires/Explosions, Unusual part (b).

- Group 1, Facility Condition, Subgroup H.

- Group 7 Value Basis Reporting, Off-normal.

When an occurrence meets the criteria for multiple groups (as shown in the above example), the category of the occurrence (Emergency. Unusual, or Off-normall shall be chosen based upon the severity of the occurrence result(s).

Occurrence categorization shall be as follows:

Group 1. Facility Condition

Group 2. Environmental

Group 3. Personnel Safety

Group 4. Personnel Radiation Protection

Group 5. Safeguards and Security

Group 6. Transportation

Group 7. Value Basis Reporting

Group 8. Facility Status

Group 9. Cross-Category Items 


\section{GROUP 1. FACILITY CONDITION}

\section{A. Nuclear criticality safoty}

Items in this subgroup, as defined in DOE Order 5000.3B, do not apply to UMTRA Project operations.

B. Fires/explosions

\section{Emergency}

- Any occurrence not under control that causes loss of building integrity (for example, damage that penetrates the outer structure of the building).

\section{Unusual}

- Any fire or explosion activating a fire suppression system li.e., sprinkler systeml, except under approved testing.

\section{Off-normal}

- Any unplanned fire that takes longer than 10 minutes to extinguish.

C. Any unplanned occurrence resulting in the serious degradation of the safety status or the analytical basis of a facility or process

\section{Unusual}

- Any occurrence preventing immediate emergency response capabilities.

\section{Off-normal}

- Any occurrence leading the contractor to limit facility operations. The limits may be either self-imposed or based on procedural requirements.

D. Loss of control of radioactive material

Items in this subgroup, as defined in DOE Order 5000.3B, do not apply to the office environments of the UMTRA Project. 
E. A deficlency such that a structure, system, or component vital to safety or program performance does not conform to stated criteria and cannot perform its intended function.

Items in this sub-group as defined by DOE Order 5000.38 do not apply to the UMTRA Project office environment.

F. Violation of procedures or inadequate procedures reaulting in adverse effects on performance, safety, or reliability.

\section{Qff-normal}

- Any violation resulting in actual equipment damage exceeding $\$ 1000$.

G. Unsatisfactory surveillance/inspections

Items in this subgroup, as defined by DOE Order 5000.3B, do not apply to UMTRA Project operations.

H. Any deficiency in a structure, system, component or facility vital to program continuity that to redesign or repair or otherwise establish the adequacy of the item shall result in significant program delay or cost.

Items categorized under this subgroup will be categorized off-normal, unusual, or emergency as appropriate, depending on the severity of the occurrence results.

I. Operations

\section{Emergency}

- Dangerous weather conditions/natural phenomena capable of breaching facility structures.

- Any request to an off-site authority for emergency assistance that results from the activation of an emergency/contingency operation or plan.

\section{Unusual}

- Weather conditions/natural phenomena causing serious disruption of facility activities.

\section{Off-normal}

- Any unplanned electrical outages or unexpected consequences from a planned outage that disrupts normal facility operations. 
OROUP 1. FACILITY CONDITION SECTION J

J. Inadequate experiment/test performance resulting in program significant delay or cost. Signiflcant program delays should take into account the time required to repeat the test to obtain any necessary data, while cost considerations should woigh the cost of repeat testing, any damage, and cleanup. 


\section{GROUP 2. ENVIRONMENTAL}

\section{A. Radionuclide releases}

Items in this subgroup do not apply to the UMTRA Project office environment.

B. Release of hazardous substances

Items in this subgroup do not apply to the UMTRA Project office environment.

C. Discovery of hazardous material contamination

Items in this subgroup do not apply to the UMTRA Project office environment.

D. Ecological resources

Items in this subgroup do not apply to the UMTRA Project office environment.

\section{E. Agreement/compliance activities}

\section{Unusual}

- Any agreement, compliance, remediation, or permit-mandated activity for which formal notification has been received from the relevant regulatory agency that a site plan is not satisfactory or that a site is considered in noncompliance with schedules or requirements. 
GROUP 3. PERSONNEL SAFETY

\section{A. Occupational iliness/injuries}

\section{Unusual}

- Any occurrence caused by DOE operations that results in a fatality or terminal injury or illness.

- Any occupational illness or injury resulting in five or more hospitalization cases, as defined by 29 CFR 1904.

\section{Off-normal}

- Any occupational illness or injury resulting in inpatient hospitalization.

\section{B. Vehicular incidents}

This subgroup refers to incidents involving government vehicles and DOE or DOE contractor-operated aircraft where an injury occurred. Group 6 also should be considered in categorization for reporting. Transportation incidents without injury should be reported in accordance with Group 6 requirements.

\section{Unusual}

- Any vehicular incident resulting in fatality(ies), injury(ies), or illness classified under Group 3, Subgroup A, Unusual occurrence.

- Any vehicle incident involving Departmental property, with fatality(ies) to a person(s) other than DOE personnel or DOE contractor personnel.

\section{Off-normal}

- Any vehicular incident with injury(ies) involving departmental property that results in a lost workday case.

- Any vehicular incident involving departmental property with injury(ies) to a person(s) other than DOE personnel or DOE contractor personnel.

\section{Miscellaneous}

Items in this subgroup, as defined in DOE Order 5000.3B, do not apply to the UMTRA Project office environment. 


\section{GROUP 4. PERSONNEL RADIATION PROTECTION}

Items in this group, as defined by DOE Order 5000.3B, do not apply to the UMTRA Project office environment. 


\section{GROUP 5. SAFEGUARDS AND SECURITY}

\section{A. Criminal acts}

\section{Emergency}

- Occurrences regarding the following:

- Bomb-related incidents: detonation, location of actual device resulting in a credible bomb threat.

- An actual sabotage event or credible sabotage threat.

- An actual terrorist attack or credible terrorist threat.

- Extortion/kidnapping of DOE or DOE contractor personnel.

\section{Unusual}

- Violent assault/battery, murder, or unjustified use of deadly force.

- Theft/diversion of government property exceeding $\$ 100,000$.

- Racketeering or other organized criminal activity on the site.

\section{Off-normal}

- Occurrences regarding the following:

- Location of a suspicious device or noncredible bomb threat.

- Noncredible terrorist threat.

- Noncredible sabotage threat.

- Theft/diversion of government property valued between $\$ 10,000$ and $\$ 100,000$.

- On-site felony conspiracies (for example, blackmail, fraud, embezzlement, extortion and forgery). 


\section{B. Loss of control of classified matter}

Items in this sub-group, as defined in DOE Order 5000.3B, do not apply to the UMTRA Project because reference is made to classified information/materials that are not part of UMTRA Project Operations.

\section{Substance abuse}

\section{Unusual}

- Possession of controlled/illegal substance(s) with intent to distribute on the site.

- Any reportable occurrence on the site at least partially attributed to the use of illegal drugs or alcohol.

\section{Off-normal}

- On-site discovery of the use, possession, or involvement of illegal drugs by DOE or DOE contractor personnel.

\section{Foreign intelligence activities}

\section{Unusual}

- Espionage, foreign intelligence activities, treason, or subversive activities by or directed at DOE or DOE contractor personnel.

\section{Off-normal}

- DOE or DOE contractor personnel who believe they might be the target of attempted exploitation by a foreign entity.

\section{E. Computer equipment/systems}

\section{Unusual}

- Discovery of a computer virus causing the disruption of facility operations.

\section{Off-normal}

- Discovery of a computer virus that results in the alteration of security features or disruption of facility operations. 


\section{F. Unplanned/unscheduled outage of site security system}

Items in this subgroup, as defined in DOE Order 5000.3B, do not apply to the UMTRA office environment.

\section{G. Demonstrations/protests}

\section{Unusual}

- Disruptive activities impeding vehicular or employee access/egress.

- Attempted or actual trespass with malicious intent.

- Malevolent activities causing property damage or bodily harm.

\section{Off-normal}

- Lawful activities warranting deployment of additional protective measures.

H. Firearms

\section{Unusual}

- Discovery of firearms on the premises.

I. Other security concerns

\section{Off-normal}

- On-site malicious mischief, disorderly conduct, or vandalism disrupting normal activity or causing damage between $\$ 10,000$ and $\$ 100,000$.

\section{J. Material control and accountability}

Items in this subgroup, as defined by DOE Order 5000.3B, do not apply to the UMTRA Project. 


\section{GROUP 6. TRANSPORTATION}

\section{A. Off-site transportation}

\section{Off-normal}

- Any transportation event involving departmental property that results in vehicular damage of more than $\$ 5000$ or, for insurance purposes, damage considered a total loss.

B. On-site transportation

Items in this sub-group as defined by DOE Order 5000.3B do not apply to UMTRA Project office environments. 


\section{GROUP 7. VALUE BASIS REPORTING}

Any occurrence specifying cost as a basis for reporting, unless otherwise stated, will be classified by the following monetary values to repair, replace, or otherwise restore a facility/system/component to acceptable operation. Costs used for reporting should be reasonable initial estimates.

\section{Unusual}

- Estimated loss or damage to DOE or other government property that amounts to $\$ 100,000$ or more, or estimated costs of $\$ 100,000$ or more for cleaning, renovating, replacing, or rehabilitating structures, equipment, or property.

\section{Off-normal}

- Estimated loss or damage to DOE or other government property that amounts to between $\$ 10,000$ and $\$ 100,000$, (for vehicles the lower limit is $\$ 5000$ or, for insurance purposes, damage considered a total loss) or estimated costs within these limits for cleaning, renovating, replacing, or rehabilitating structures, equipment, or property. 


\section{GROUP 8 FACILITY STATUS}

A. Unscheduled shutdowns

Unusual

- Any unscheduled shutdown of 1 week or longer.

\section{Off-normal}

- Any unscheduled shutdown of a facility, process or operation longer than 2 days.

\section{B. Extended unscheduled shutdowns}

\section{Unusual}

- Any increase in shutdown schedule that exceeds 50 percent of the planne; schedule at the time of extension or 1 month.

C. Any unplanned occurrence in any portion of a program conducted in accordance with approved requirements and procedures that results in delaying the siart-up of a new facility, process, etc.

Items in this subgroup, as defined by DOE Order 5000.3B, do not apply to the UMTRA Project office environment. 


\section{GROUP 9. CROSS-CATEGORY ITEMS}

A. A series of related occurrences that individually do not warrant reporting under preceding criteria, but that collectively are considered significant enough to warrant reporting. The severity of this category depends upon the severity of the occurrence result(s).

B. A near-miss to one of the reporting classifications under preceding categories.

\section{Unusual Occurrence}

- An occurrence wherein the conditions needed to cause an Unusual occurrence existed (all barriers failed).

\section{Off-normal}

- An occurrence wherein the conditions needed cause a reportable occurrence were prevented from existing by one remaining barrier after other barriers had been compromised (for example, one additional independent failure/degradation was necessary for event initiation.

C. Identification of potential concerns or issues deemed worthy of reporting.

Items categorized under this subgroup will be categorized off-normal, unusual, or emergency as appropriate, depending on the severity of the occurrence result(s). 


\subsection{LIST OF CONTRIBUTORS}

The following individuals contributed to the preparation of this report.

\begin{tabular}{ll}
\hline Name & Contribution \\
\hline $\begin{array}{l}\text { Karen Atkiss } \\
\text { Barry Stewart }\end{array}$ & Authors \\
Mike Bradshaw & Technical assistance \\
Ernie Couch & \\
Mark Miller & \\
Jarus Polland & \\
Robert Saar & \\
Linda Ulland & \\
Clyde Yancey & \\
D. Anderson & \\
K. Walston & Technical editing; document coordination \\
WordCenter, Inc. & Word processing \\
\hline
\end{tabular}




\subsection{REFERENCES}

DOE ORDERS

5400.5 5000.3B, "Occurrence Reporting and Processing of Operations Information" 1/19/93, effective $2 / 22 / 93$

\section{CODE OF FEDERAL REGULATIONS}

40 CFR Part 302

29 CFR Part 1904

49 CFR Part 171.8

\section{RADIOLOGICAL CONTROL MANUAL}

\section{CERCLA}

POT-E 10594

RCRA

OSHA of 1970

\section{NOTICES}

N5400.9 

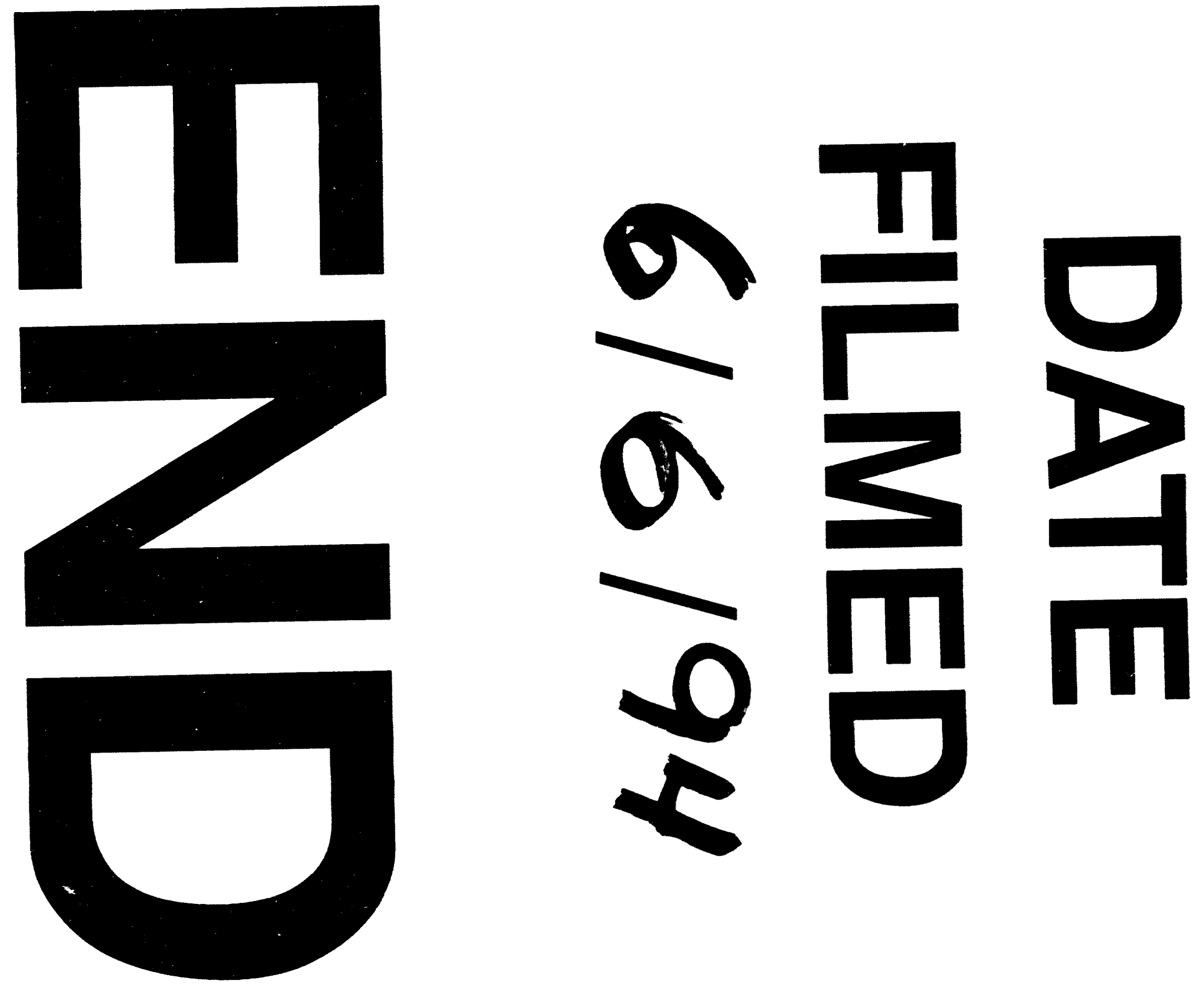
